\title{
MENIMBANG (ULANG) KEKERASAN DALAM ALKITAB DARI PERSPEKTIF KATOLIK
}

\author{
INDRA TANUREJA*
}

\begin{abstract}
Abstrak: Kekerasan dalam Alkitab boleh dikatakan merupakan sebuah topik alkitabiah yang unik dan abadi, baik dari sudut pandang akademis maupun spiritual. Orang tidak hanya perlu memahaminya untuk orang lain, tetapi juga untuk diri sendiri. Sejak Marcion di abad pertama sampai saat ini, meskipun sudah amat banyak tulisan dihasilkan, tidak pernah ada suatu solusi yang memuaskan semua pihak. Tulisan ini menawarkan sudut pandang yang jarang disentuh, yaitu sudut pandang Gereja Katolik. Membaca Alkitab sebagai orang Katolik berarti membaca dengan memperhatikan juga ajaran-ajaran Gereja tentang (pokok-pokok tertentu dari) Alkitab sebagaimana terungkap dalam dokumen-dokumen resmi Gereja. Ajaran Gereja khususnya Dei Verbum artikel 11 dan 12 memuat paling tidak pemahaman akan tiga hal yang dapat membuka kemungkinan untuk memahami persoalan ini secara lebih utuh. Pokokpokok yang dimaksud adalah soal inspirasi, paham tentang Alkitab, dan kesatuan seluruh Alkitab sebagai kunci penafsiran Alkitab dalam Gereja. Pembacaan Alkitab secara menyeluruh menunjukkan bahwa klim kekerasan dalam Alkitab adalah sebuah klim sepihak yang tidak memperhatikan keseluruhan Alkitab sebagaimana dipahami dan diterima Gereja sebagai buku iman.
\end{abstract}

Kata-kata Kunci: Kekerasan dalam Alkitab, Ajaran Gereja, Dei Verbum, inspirasi, paham tentang Alkitab, kesatuan seluruh Alkitab, jenis sastra.

Abstract: Violence in the Bible could be considered a unique eternal theme in the Bible, be it from academic or spiritual perspective. One needs to understand it not only for helping others, but also for himself. Since Marcion in the first century up to our time, there has been no solution which is acceptable and could satisfy everybody, notwithstanding the abundance literature on this topic. To read the Bible as Catholic means to

* Indra Tanureja, Program Studi Ilmu Teologi, Fakultas Teologi, Universitas Sanata Dharma, Jl. Kaliurang Km. 7, Jogjakarta 55011. E-mail:don_indrasan@yahoo.com. 
read it employing the Church's teachings on the Bible which are found in the official Church documents as the hermeneutical key. The teaching of the Church especially Dei Verbum 11 and 12 offers an understanding on three important points that could be useful for comprehending the topic in a more comprehensive way. Those three points are the notion of biblical inspiration, the Catholic understanding of the Bible and the unity of the Bible. They could be the key to a correct interpretation of the Bible within the Church. The holistic reading of the Bible shows that the claim of biblical violence is actually a one-sided claim that does not pay fair attention to the unity of the Bible as a whole as it is understood and accepted by the Church as the book of faith.

Keywords: Violence in the Bible, Church's official teaching, Dei Verbum, divine inspiration, notion of the Bible, the unity of the Bible, literary genre.

\section{PENGANTAR}

Persoalan Alkitab dan kekerasan, di satu pihak, merupakan sebuah persoalan yang sudah amat kuno. Tetapi di lain pihak, persoalan ini tetap menjadi topik yang menarik sampai sekarang ini, sekian puluh abad setelah Alkitab ditulis. Terbukti sampai saat ini sudah ada begitu banyak buku dan tulisan yang mengambil tema ini. Fakta ini hanya dapat berarti satu hal, yaitu bahwa persoalan kuno ini ternyata tidak pernah mendapatkan pemecahan yang tuntas, sekali untuk selama-lamanya dan memuaskan semua pihak. Selalu saja ada kemungkinan untuk memberikan jawaban baru dan segar, meskipun mungkin tidak akan mampu seratus persen mengubur masalah itu untuk selama-lamanya.

Tema ini juga unik. Ketika orang mendekati persoalan ini, dia sadar bahwa dia tidak dapat mendekatinya secara dingin, tanpa keterlibatan apa-apa. Saya berjuang keras memahami kisah-kisah kekerasan dalam Alkitab bukan hanya karena ini merupakan tuntutan dari pihak di luar saya; tetapi secara pribadi, saya sendiri juga terlibat di sana. Hasil permenungan yang saya tawarkan, juga saya tawarkan-bahkan pertamatama-kepada diri saya sendiri. 
Harus diakui bahwa tulisan ini juga bukan merupakan kali pertama penulis berhadapan dengan tema ini. Sebelumnya, beberapa kali penulis mesti menyampaikan pemikiran-yang juga berarti pergulatan pribadi penulis_ entah dalam forum resmi, di hadapan suatu sidang pendengar tertentu, di ruang kuliah, atau forum tidak resmi, seperti dalam pertemuan spontan dengan para sahabat.

Mengingat bahwa tema ini merupakan sebuah tema yang tidak pernah selesai direfleksikan, penulis sangat sadar bahwa hasil refleksi yang tertuang ini bukan sesuatu yang sama sekali baru. Gagasan ini adalah sesuatu yang didasarkan pada pemikiran sebelumnya yang kemudian disempurnakan melalui refleksi dan studi yang terus menerus berlangsung. Ibaratnya sebuah bola salju, hasil pemikiran ini sudah semakin membesar dibandingkan dengan hasil beberapa waktu yang lalu. Meskipun demikian, penulis juga sadar bahwa bola salju ini masih jauh dari kaki gunung saat bola salju itu akan berhenti bergulir dan berhenti berproses. Penulis sendiri tidak tahu apakah kita memang akan dapat sampai pada titik itu.

\section{STATUS QUAESTIONIS}

Pembicaraan tentang kekerasan dalam Alkitab, khususnya manakala Yang Ilahi sendiri terlibat dalam kekerasan tersebut, entah langsung maupun tidak langsung, sudah muncul sejak zaman Marcion dari Sinope (110-160 M). Gambaran tentang Allah dalam Perjanjian Lama yang begitu berbeda atau bahkan bertolak belakang dengan gambaran Allah, Bapa Tuhan kita Yesus Kristus yang terdapat dalam Perjanjian Baru, membuat Marcion galau dan terusik. Akhirnya ia sampai pada suatu kesimpulan ekstrem bahwa ada dua Allah: yang satu baik (ungkapan Marcion seperti dikutip oleh Tertulianus: "mild, placid and simply good and excellent"), ${ }^{1}$ yaitu Allah Yesus Kristus yang

1 Tertullianus, Against Marcion, I.6 dikutip dari edisi Peter Holmes (trans.), The Five Books of Quintus Sept. Flor: Tertullianus against Marcion (Edinburgh: T\&T Clark, 1868), p. 10. 
terdapat dalam surat-surat Paulus, dan yang lain "jahat," atau mungkin lebih tepat, bukan jahat melainkan adil dan terlalu kaku² (" judicial, harsh and mighty in war"), yaitu Allah orang Yahudi yang terdapat dalam Perjanjian Lama. Tidak heran jika akhirnya Marcion hanya mau menerima Injil Lukas dan sepuluh surat Paulus sebagai Kitab Sucinya. Seluruh Perjanjian Lama dan tulisan-tulisan Perjanjian Baru lainnya ia singkirkan dari kanonnya.

Alkitab yang dibaca Marcion adalah juga Alkitab yang kita baca. Teks-teks terror (text of terror), ${ }^{3}$ yaitu teks-teks yang menggambarkan kekerasan, juga tetap ada di situ. Dalam hal ini, harus diakui bahwa ada beberapa teks favorit yang selalu ditunjukjika kita mau berbicara tentang tema kekerasan dalam Alkitab. Teks-teks yang menimbulkan persoalan itu tidak dapat dibuang atau dihilangkan. Yang berubah-ubah adalah pembacanya, mulai dari Marcion di zaman dulu sampai dengan kita yang hidup di zaman modern ini. Di zaman sekarang ini, pandangan Marcion akan Allah itu muncul lagi, misalnya, dalam gagasan Richard Dawkins yang dalam bukunya, The God Delusion, menggambarkan demikian:

The God of the Old Testament is arguably the most unpleasant character in all fiction: jealous and proud of it; a petty, unjust, unforgiving controlfreak; a vindictive, bloodthirsty ethnic cleanser; a misogynistic, homophobic, racist, infanticidal, genocidal, filicidal, pestilential, megalomaniacal, sadomasochistic, capriciously malevolent bully. ${ }^{4}$

Kendati berhadapan dengan teks yang sama, pembaca yang berbeda menghasilkan lukisan yang berbeda pula. Dengan kata lain, peran pem-

2 Bart D. Ehrman, Lost Christianities (New York: Oxford University Press, 2003), p. 105. Tentang Marcion, dapat dilihat juga Heikki Räisänen, "Marcion" in A Companion to Second-Century Christian 'Heretic,' eds. Antti Marjanen \& Petri Luomanen (Leiden: Brill, 2005), pp. 100-124. Karya Marcion sendiri sudah tidak ditemukan lagi. Satusatunya sumber tentang gagasan Marcion adalah tulisan Tertullianus, Adversus Marcionem, yang terdiri dari 5 jilid.

3 Meminjam istilah Phyllis Trible yang dipakai sebagai judul bukunya, Texts of Terror: Literary-Feminist Reading of Biblical Narratives (Philadelphia: Fortress Press, 1984).

4 Richard Dawkins, The God Delusion (London: Bantam Press, 2006), p. 31. 
baca rupanya menjadi penting dalam menentukan apakah sebuah teks memang menghasilkan efek keheranan dan kengerian, ketakutan dan kekecewaan, atau justru sebaliknya. Bahkan tidak dapat dipungkiri bahwa pembaca pula yang menentukan sehingga teks-teks seperti ini menjadi pembenaran untuk menindas orang lain dengan dalih dogmadogma religius. ${ }^{5}$

Meskipun pembaca memegang peranan penting dalam memaknai sebuah teks, masih ada satu faktor lain yang juga menentukan, yaitu teks itu sendiri. Berita dan cerita kekerasan menimbulkan persoalan besar baik bagi Marcion maupun pembaca sekarang, karena berita dan cerita tersebut terdapat dalam Alkitab. Hidup kita sebenarnya dipenuhi dengan aneka macam berita dan cerita tentang kekerasan dalam aneka bentuknya. Tetapi tidak pernah berita-berita itu menjadi masalah besar bagi kita seperti yang dihasilkan oleh cerita-cerita alkitabiah. Seandainya tidak ada keyakinan bahwa Alkitab mempunyai posisi tertentu dalam hidup pembaca-nya, Alkitab tidak lebih dari sekedar kumpulan cerita kuno sama dengan kisah-kisah lainnya. ${ }^{6}$ Rupanya ada keyakinan dan harapan tertentu dari pembaca terhadap sebuah dokumen yang disebut Alkitab atau Kitab Suci. Ketika keyakinan ini berhadapan dengan fakta yang sama sekali bertentangan, pembaca mengalami apa yang biasa disebut dengan cognitive dissonance. Inilah yang menimbulkan ketegangan psikologis dalam diri pembaca.

Dengan demikian, dalam membicarakan tema kekerasan dalam Alkitab rasanya ada dua hal yang perlu mendapat perhatian lebih. Yang pertama berkaitan dengan pembaca yang menjadi penentu makna dari sebuah teks alkitabiah yang ada di tangannya. Masih berkaitan dengan ini adalah paham pembaca mengenai Alkitab itu sendiri. Orang mesti memutuskan apa arti Alkitab bagi dirinya sebelum ia mengartikannya. ${ }^{7}$

5 Bdk. Eryl W. Davies, The Immoral Bible: Approaches to Old Testament Ethics (London New York: T\&T Clark, 2010), p. 1.

6 Eryl W. Davies, The Immoral Bible, p. 3.

7 Jerome F.D. Creach, Violence in Scripture (Louisville: Westminster John Knox, 2013), p. 3. 
Yang kedua, adalah bagaimana teks dengan kedudukan istimewa itu harus dimengerti oleh pembacanya. Pembahasan dua hal inilah yang penulis tawarkan dalam tulisan ini.

Justru karena pembaca memegang peranan penting dalam membaca teks, maka pada kesempatan awal ini perlu disampaikan terlebih dahulu posisi penulis yang dalam hal ini berperan sebagai pembaca teks. Penulis adalah seorang Katolik yang mempelajari Alkitab dan ajaran-ajaran Gereja. Oleh karena itu, paham mengenai Alkitab yang ditawarkan tidak dapat dilepaskan dari rambu-rambu yang disampaikan oleh ajaran Gereja Katolik. Kekhasan pendekatan Katolik ini yang rasanya tidak pernah disentuh dalam menghadapi problematika kekerasan dalam Alkitab. Penulis percaya bahwa pendekatan ini dapat menyumbangkan sesuatu yang bermanfaat untuk menghadapi persoalan ini.

\section{PEMBACA}

Dalam pembicaraan tentang pembaca ini, ada dua hal yang patut mendapat perhatian. Yang pertama, berkaitan dengan paham pembaca mengenai Alkitab, dan yang kedua, yang juga berkaitan dengan yang pertama, adalah bagaimana pembaca seharusnya membaca kisah-kisah alkitabiah.

\section{Apa itu Alkitab?}

Kata-kata pemazmur, "Firman-Mu itu pelita bagi kakiku dan terang bagi jalanku" (Mzm. 119:105) kiranya menjadi suatu pengakuan iman akan Alkitab bagi orang beriman. Pengakuan ini menyangkut dua hal: pertama, Alkitab adalah Firman Allah; dan kedua, Firman itu merupakan pem-bimbing dalam hidup mereka. Di sini kita dapat merasakan sebuah ironi. Pandangan kita tentang Allah dan kepekaan kita tentang moralitas yang memampukan kita menilai bahwa gambaran tertentu dalam Alkitab bertentangan dengan moralitas, sebenarnya berasal dari gambaran tentang Allah serta moralitas yang diajarkan-Nya sendiri lewat Firman-Nya. ${ }^{8}$

8 Bdk. Nicholas Wolterstorf, "Reading Joshua" in Divine Evil?: The Moral Character of 
Yang perlu diklarifikasi adalah ungkapan pertama, yaitu Alkitab adalah Firman Allah. Apa persisnya yang dimaksud dengan ungkapan tersebut? Harus diakui bahwa ungkapan ini dapat mempunyai kandungan makna yang bermacam-macam. Bagaimana pun juga asal-usul ilahi dari Alkitab mau dimengerti, yang memberikan bentuk terakhir atau yang menuangkan Firman Ilahi itu menjadi bentuk tertulis adalah manusia. Hanya saja, tidak ada kesepakatan sejauh mana peranan manusia dalam menuliskan Firman ilahi itu. Ada pendapat yang memberikan kepada penulis manusiawi ini peranan yang amat terbatas; tetapi ada pula yang menganggap bahwa peranan mereka cukup besar.

Dalam situasi seperti ini, sebagai pembaca Katolik, kita dapat berpaling pada ajaran Gereja tentang pokok yang dimaksud. Gereja Katolik, dalam salah satu dokumen yang dihasilkan oleh Konsili Vatikan II, Dei Verbum, menuliskan tentang hal ini demikian:

Yang diwahyukan oleh Allah dan yang termuat serta tersedia dalam Kitab suci telah ditulis dengan ilham Roh Kudus. Sebab Bunda Gereja yang kudus, berdasarkan iman para Rasul, memandang Kitab-kitab Perjanjian Lama maupun Baru secara keseluruhan, beserta semua bagian-bagiannya, sebagai buku-buku yang suci dan kanonik, karena ditulis dengan ilham Roh Kudus (lih. Yoh. 20:31; 2Tim. 3:16; 2Ptr. 1:19-21;3:15-16), dan mempunyai Allah sebagai pengarangnya, serta dalam keadaannya demikian itu diserahkan kepada Gereja. Tetapi dalam mengarang kitab-kitab suci itu Allah memilih orang-orang, yang digunakan-Nya sementara mereka memakai kecakapan dan kemampuan mereka sendiri, supaya — sementara Dia berkarya dalam dan melalui merekasemua itu dan hanya itu yang dikehendaki-Nya sendiri dituliskan oleh mereka sebagai pengarang yang sungguh-sungguh. ${ }^{9}$

Ada dua hal penting yang mau diungkapkan di sini. Pertama, Kitab Suci itu dituliskan berdasarkan ilham atau inspirasi ilahi. Inspirasi ilahi inilah yang mendorong pengarang manusiawi menulis. Kedua,

the God of Abraham, ed. Michael Bergmann et. al. (New York: Oxford University, 2011), p. 346.

9 Dei Verbum (untuk selanjutnya disingkat DV), 11. Italic ditambahkan. 
pengarang manusiawi ini tetap berperan sebagai pengarang yang sungguh-sungguh (veri auctores). Dengan kata lain, mereka tidak menerima dikte dari Roh Ilahi melainkan mempunyai kebebasan cukup dalam menulis. Memang dalam hal ini, konsili tidak menjelaskan bagaimana persisnya inspirasi terjadi. Konsili hanya mengatakan bahwa inspirasi itu ada, tetapi tidak menjelaskan bagaimananya.

Keengganan Konsili untuk berbicara secara tegas tentang inspirasi kiranya menjadi jelas kalau kita memperhatikan bagaimana Dei Verbum 11 di atas mengolah sumbernya. Dalam Dei Verbum artikel 1 dikatakan bahwa Konsili bermaksud menyajikan ajaran yang asli tentang wahyu ilahi dengan mengikuti jejak "Konsili Trente dan Konsili Vatikan I." Berkaitan dengan inspirasi Alkitab dapat diperhatikan apa yang ditulis oleh dua konsili terdahulu itu. Menurut Konsili Trente dalam Sessi IV pada tanggal 8 April 1546: "... this truth and discipline are contained in the written books, and the unwritten traditions which, received by the Apostles from the mouth of Christ himself, or from the Apostles themselves, the Holy Ghost dictating (Spiritu Sancto dictante), have come down even unto us...." 10

Sementara itu Konsili Vatikan I mengatakan:

These [books] the Church holds to be sacred and canonical, not because, having been composed by simple human industry, they were later approved by her own authority, nor merely because they contain revelation without error, but because, having been written by the inspiration of the Holy Spirit (Spiritu Sancto inspirante), they have God for their author and were delivered as such to the Church. ${ }^{11}$

10 Konsili Trento, Sesi IV, dekrit I tentang Kitab-kitab Kanonik diterjemahkan oleh James Waterworth (1848). http://www.bible-researcher.com/trent1.html. Diakses pada 18 Juni 2014. Frase Spiritu Sancto dictante oleh Béchard ternyata diterjemahkan the inspiration of the Holy Spirit. Dean P. Béchard, The Scripture Documents (Collegeville: The Liturgical Press, 2002), p. 3. Sementara ungkapan yang sama dalam ensiklik Leo XIII Providentissimus Deus (18 Nopember 1893) yang dalam bahasa Latin berbunyi Spiritu Sancto inspirante, oleh Béchard diterjemahkan the dictation of the Holy Spirit. Dean P. Béchard, The Scripture Documents, p. 55. Dalam pandangan Béchard tampaknya kata "inspirante" dan "dictante" dapat dipertukarkan begitu saja.

11 Konstitusi Dogmatis tentang Iman Katolik Dei Fillius, Bab II tentang Pewahyuan, dalam sessi III Konsili Vatikan I, 24 April 1870. Teks dikutip dari Dean P. Béchard, The Scripture Documents, p. 17. 
Jika kita perhatikan, ajaran Vatikan I sudah bergeser dari dictante (dictation) menjadi inspirante (inspiration). Dalam hal ini Dei Verbum tidak mengikuti pandangan Trente, tetapi mengikuti pandangan Vatikan I. Fakta ini dapat diartikan bahwa Konsili Vatikan II memang tidak mau berbicara secara lugas dan jelas tentang inspirasi Alkitabiah, misalnya dengan mengatakan bahwa inspirasi terjadi melalui dikte dari Roh Kudus seperti ditegaskan oleh Konsili Trente. Tampaknya cukuplah bagi Konsili untuk menegaskan bahwa Alkitab ditulis dengan inspirasi ilahi, entah bagaimana hal ini mau dipahami. ${ }^{12}$ Dengan demikian, boleh dikatakan bahwa Alkitab adalah Firman Allah dalam bahasa manusia (bdk. DV, 13).

\section{Bagaimana Alkitab mesti dibaca?}

Justru karena manusia diikutsertakan dalam penulisan Kitab Suci "dengan memakai kecakapan dan kemampuan mereka sendiri," maka dimensi manusiawi ini tidak dapat diabaikan dalam memahami tulisantulisan suci ini.

Adapun karena Allah dalam Kitab suci bersabda melalui manusia secara manusia, maka untuk menangkap apa yang oleh Allah akan disampaikan kepada kita penafsir Kitab suci harus menyelidiki dengan cermat, apa yang sebenarnya mau disampaikan oleh para penulis suci, dan apa yang mau ditampakkan oleh Allah dengan kata-kata mereka (DV, 12).

Ajaran Konsili Vatikan II boleh dikatakan merupakan satu-satunya ajaran tentang Kitab Suci yang paling komprehensif yang pernah dikeluarkan oleh Gereja Katolik. Sebagai ajaran Gereja, maka arahan ini kiranya mesti diperhatikan oleh umat Katolik, khususnya para penafsir Katolik. ${ }^{13}$

12 Komisi Kitab Suci Kepausan pada tahun 2013 sudah mengakhiri studi mereka tentang "Inspiration and Truth in the Bible." Tetapi sampai saat ini belum ada dokumen yang dikeluarkan tentang hal tersebut.

13 Dokumen Dei Verbum yang dikategorikan sebagai sebuah "konstitusi dogmatis", merupakan sebuah dokumen otoritatif karena berbicara tentang doktrin Gereja dan 
Jika diperhatikan dengan saksama, dipandang dari sudut pandang perkembangan ilmu tafsir, maka arahan Konsili Vatikan II yang dikutip di atas ini bukan sesuatu yang istimewa. Tampak jelas bahwa di sini Konsili berbicara tentang metode historis kritis, meskipun kata ini tidak muncul sekali pun. Kalau Gereja Katolik secara resmi mengadopsi metode ini pada tahun 1965, maka tampak bahwa Gereja Katolik sebenarnya sudah terlambat beberapa abad. Ketika orang sudah sampai pada keyakinan bahwa di balik Pentateukh terdapat sekurang-kurangnya empat tradisiYahwis, Elohis, Priester, dan Deuteronomis-Gereja (Katolik) masih keukeuh (bersikeras) mempertahankan bahwa Musa adalah pengarang Pentateukh. ${ }^{14}$

Pendekatan ini sebenarnya memungkinkan kita untuk melihat adanya potensi perbedaan antara gambaran Allah yang sesungguhnya dengan gambaran Alkitab tentang Allah. Eric Siebert menekankan perlunya memperhatikan "the human origins of the Bible with full seriousness and to distinguish between the Bible's portrayals of God and God's true character" $^{15}$ untuk menelaah masalah kekerasan di dalam Alkitab. Thomas Aquinas pernah mengatakan bahwa bahasa teologi sebenarnya adalah analogi. Kita hanya dapat berbicara tentang Allah dengan menggunakan bahasa analogi. Kalau demikian, gambaran tentang Allah juga yang ada di dalam Alkitab, harus dipahami secara analogi. Dalam kalimat "Allah itu baik" dan "Ibu saya baik," kata "baik" dipakai secara analog; tidak seratus persen sama, tetapi juga tidak seratus persen berbeda.

Dalam rangka menafsirkan Alkitab, Konsili memberi catatan:

Untuk menemukan maksud para pengarang suci antara lain perlu diperhatikan juga "jenis-jenis sastra." Sebab dengan cara yang ber-

dihasilkan oleh sebuah konsili ekumenis yang melibatkan para uskup dan teolog dari seluruh dunia. Bdk. Marc Zvi Bettler, Peter Enns, Daniel Harrington, The Bible and the Believers (New York: Oxford University, 2011), p. 83.

14 Pontifical Biblical Commission, "On the Mosaic Authorship of the Pentateuch" tertanggal 27 Juni, 1906 dalam Dean P. Béchard, The Scripture Documents, pp. 188-189; Enchiridion Biblicum, no. 181-184.

15 Eric A. Seibert, Disturbing Divine Behavior (Minneapolis: Fortress Press, 2009), p. 5. 
beda-beda kebenaran dikemukakan dan diungkapkan dalam nasnas yang dengan aneka cara bersifat historis, atau profetis, atau poetis, atau dengan jenis sastra lainnya. Selanjutnya penafsiran harus mencari arti, yang hendak diungkapkan dan ternyata jadi diungkapkan oleh pengarang suci dalam keadaan tertentu, sesuai dengan situasi jamannya dan kebudayaannya, melalui jenis-jenis sastra yang ketika itu digunakan. Sebab untuk mengerti dengan seksama apa yang oleh pengarang suci hendak dinyatakan dengan tulisannya, perlu benarbenar diperhatikan baik cara-cara yang lazim dipakai oleh orangorang pada zaman pengarang itu dalam merasa, berbicara atau bercerita, maupun juga cara-cara yang pada zaman itu biasanya dipakai dalam pergaulan antar manusia (DV, 12).

Secara ringkas, yang mau disampaikan konsili adalah bahwa pengenalan jenis sastra (literary genre) merupakan salah satu hal yang amat penting dalam menafsirkan Alkitab. ${ }^{16}$ Jenis sastra secara sederhana dapat diartikan sebagai sebuah karya sastra yang disusun dengan bentuk, susunan dan tujuan tertentu, dan oleh karena itu, mesti dibaca dengan cara tertentu pula. Dengan demikian, kesalahan dalam menangkap “jenis sastra" menanggung bahaya menyalahartikan makna dari teks yang sedang dibaca. Oleh karena itu, untuk dapat membaca Alkitab dengan tepat, dibutuhkan sebuah kompetensi susastra (literary competence) untuk mengenali jenis sastra (genre recognition) sebuah teks yang sedang kita baca. ${ }^{17}$ Herman Gunkell pernah mengatakan, "Anyone investigating an author without knowing the genre he uses is building a house beginning with the roof." 18

Dalam kaitan dengan ini, kita dapat mengambil contoh kitab Yosua 6-11 yang (hampir) selalu disebut dan dikutip sebagai contoh dari kisah kekerasan Allah di dalam Alkitab. Pertanyaan yang dapat diajukan adalah, apakah kisah-kisah tersebut memang sungguh-sungguh terjadi?

16 Bdk. John Barton, Reading the Old Testament (London: Darton, Longman, and Todd, 1984), pp. 11-19. Juga Patricia M. McDonald, God \& Violence (Scotdalle: Herald Press, 2004), pp. 18-19.

17 Bdk. John Barton, Reading the Old Testament, p. 14.

18 Seperti dikutip oleh Eric A. Seibert, Disturbing Divine Behavior, p. 105. 
Atau apakah penulis memang bermaksud melaporkan sebuah peristiwa historis tertentu? Berhadapan dengan teks seperti ini, Agustinus pada abad keempat memberikan pertimbangan demikian, "It is necessary to recognize as figurative that which in a divine discourse cannot refer in its literal meaning to the honesty of the customs or to the truth of the faith" (De Doctrina Cristiana, 3,33). Menurut bukti-bukti alkitabiah serta penemuan arkeologis, banyak ahli berpendapat bahwa kitab Yosua 6-11 hampir pasti bukan sebuah laporan historis dari peristiwa yang terjadi. ${ }^{19}$ Kalau demikian lalu apa? Dari sudut jenis sastra, narasi seperti itu disebut 'historiografi kuno.' Meskipun kisah seperti itu mengandung banyak unsur historis yang dapat dipertanggungjawabkan, penulis historiografi kuno tidak berminat untuk membuat sebuah laporan lengkap sistematis mengenai detil-detil apa yang sesungguhnya terjadi. Salah satu karakteristik dari historiografi kuno yang ditawarkan oleh Seibert adalah bahwa "Old Testament Narratives were more concerned with literary persuasion than with historical objectivity." 20 Tidak mengherankan jika para penulis itu menggambarkan sesuatu yang mungkin tidak dapat diterima, tetapi mempunyai daya persuasif yang kuat. Model menulis seperti inilah, yang bukan sesuatu yang asing dalam kultur Timur Dekat Kuno, ${ }^{21}$ yang telah mengecoh banyak orang saat membaca Kitab Yosua. ${ }^{22}$

Kalau unsur-unsur manusiawi dalam penulisan Alkitab diperhitungkan, penulis merasa bahwa sebenarnya persoalan kekerasan di dalam Alkitab - entah itu gambaran Allah yang begitu kejam atau kisahkisah alkitabiah yang mengesankan keras dan kejam-tidak perlu menjadi beban yang begitu berat bagi kita. Philip Jenkins, seorang profesor sejarah pada Baylor University, menulis, “That (= pengarang

19 Ini merupakan rangkuman dari studi atas Yos. 6-11 yang dibuat Seibert dalam Disturbing Divine Behavior, pp. 97-104.

20 Eric A. Seibert, Disturbing Divine Behavior, p. 108.

21 Contoh dapat dilihat dalam Lori L. Lowrett, Joshua and the Rhetoric of Violence (Sheffield: Sheffield Academic Press, 1996), p. 67.

22 Paul Copan, Is God a Moral Monster? (Grand Rapids: BakerBooks, 2011), p. 171. 
manusia dalam penulisan Alkitab) leaves open some chance of blaming embarrassing views on that person's own prejudices." 23

Satu hal lagi perlu penulis tambahkan sebelum kita beralih pada unsur penting yang kedua, yaitu teks itu sendiri. Masih dalam Dei Verbum, disampaikan semacam rambu-rambu yang mesti diperhatikan dalam menafsirkan Alkitab.

Akan tetapi Kitab suci ditulis dalam Roh Kudus dan harus dibaca dan ditafsirkan Roh itu juga. Maka untuk menggali dengan tepat arti nasnas suci, perhatian yang sama besarnya harus diberikan kepada isi dan kesatuan seluruh Alkitab, dengan mengindahkan Tradisi hidup seluruh Gereja serta analogi iman (DV, 12).

Paragraf ini mau mengatakan bahwa seorang penafsir Katolik mesti memperhatikan tiga hal, yakni isi dan kesatuan seluruh Alkitab, Tradisi Hidup Gereja, dan analogi iman. Yang relevan bagi pembicaraan kita adalah yang pertama, yaitu memperhatikan isi dan kesatuan seluruh Alkitab. Sebenar-nya hal ini pun tidak amat khas ajaran Katolik, karena mirip dengan canonical criticism yang dipopulerkan oleh Brevard S. Childs. Yang dimaksud adalah bahwa penafsiran salah satu teks alkitabiah tidak dapat bertentangan dengan teks-teks Alkitab yang lain. Pengandaiannya kiranya jelas, yakni bahwa bermacam-macam tulisan yang mem-bentuk Alkitab, ditulis oleh inspirasi Roh yang satu dan sama. ${ }^{24}$ Oleh karena itu, karya Roh yang satu tidak dapat bertentangan dengan karya Roh yang lain. Dalam Bahasa Paus Benediktus XVI dalam anjuran apostolik post-sinodal Verbum Domini yang dikeluarkan pada

23 Philip Jenkins, “Dark Passages” dalam Boston Globe edisi 8 Maret 2009. http:// www.boston.com/bostonglobe/ideas/articles/2009/03/08/dark_passages / ?page=full. Diakses pada 18 Juni 2014. Dalam artikel itu, Jenkins membandingkan Kitab Suci Kristiani dan Al Quran dan menyimpulkan bahwa Alkitab Kristiani tidak lebih sedikit dari Al Quran dalam menginspirasikan kekerasan. Secara lebih lengkap, gagasan ini dapat ditemukan juga dalam bukunya, Laying Down the Sword. Why We Can't Ignore the Bible's Violent Verses (New York: HarperOne, 2011), pp. 6-13.

24 Bdk. Tom Jacobs, Konstitusi Dogmatis "Dei Verbum" tentang Wahju Ilahi (Yogyakarta: Kanisius, 1969), hlm. 172. 
30 September 2010, kesatuan Alkitab ini merupakan kriteria utama bagi sebuah hermeneutika iman yang benar (a correct hermeneutic of faith). ${ }^{25}$

Lebih lanjut, dalam dokumen yang sama Paus Benediktus XVI menegaskan bahwa pewahyuan Allah ini berakar kuat pada sejarah. ${ }^{26}$ Oleh karena itu kemudian dinyatakan bahwa "God's plan is manifested progressively and it is accomplished slowly." Dengan kata lain, teks-teks yang bernuansa kekerasan dan immoral ini, yang disebut The "Dark" Passages of the Bible, perlu dipahami sebagai teks yang lahir dari sebuah kultur yang secara historis masih ada dalam perkembangan. Teks-teks seperti ini tidak dapat dipahami secara terpisah begitu saja, tetapi mesti dipahami dalam kesatuan dengan teks-teks lain yang dalam perjalanan sejarah menyempurnakan gagasan-gagasan yang sebelumnya.

Kalau pertimbangan-pertimbangan ini kita terapkan dalam persoalan kita, ini berarti bahwa kita mesti membaca problem kekerasan dalam Alkitab dalam keseluruhan dan kesatuan Alkitab itu sendiri. Apakah memang Alkitab kita mengajarkan secara bulat utuh hanya teks-teks yang berbau kekerasan? Jawabannya jelas: tidak. Dua model teks ini perlu dilihat bersama. Marcion melihat dua model itu, dan mengambil satu keputusan tertentu. Gereja melihat dua model itu, dan mengambil keputusan yang berbeda dari yang diambil Marcion. Pada bagian berikut ini, kita akan melihat bahwa sebenarnya Alkitab sendiri menawarkan tidak hanya satu suara, tetapi memberikan kesempatan untuk mencari second opinion dalam beberapa hal tertentu.

\section{TEKS}

Berhadapan dengan Marcion yang menentukan kanon Kitab Sucinya sendiri, Gereja juga menentukan apa yang menjadi miliknya, apa yang diakuinya sebagai bagian Alkitab. Marcion membuang semua teks yang dianggapnya berkaitan dengan Allah orang Yahudi yang menjadi sumber kekerasan dan kekejaman, terutama Perjanjian Lama. 
Sebaliknya, Gereja menerima semuanya, baik Perjanjian Baru maupun Perjanjian Lama, dengan resiko bahwa Gereja mesti hidup dalam ketegangan. Gereja tidak memilih Alkitab yang lebih menghadirkan Allah yang penuh kasih, tetapi ia juga tidak memilih Alkitab yang menampilkan Allah yang beringas. Gereja juga tidak menyembunyikan teks-teks tertentu yang dirasa dapat menjadi sandungan bagi orang tertentu. ${ }^{27}$ Dengan kata lain, Alkitab kanonik yang menjadi pedoman hidup kristen kita adalah Alkitab yang sekaligus mengandung kekerasan dan kelembutan, kalau boleh dikatakan demikian. Pilihan Gereja ini sungguh sesuatu yang istimewa dan sungguh mengagumkan. Seandainya dulu Gereja mengikuti Marcion, mungkin ketegangan seperti ini tidak akan pernah muncul. Tetapi ternyata bukan itu yang dipilih Gereja.

Pada bagian ini, secara konkret, kita akan memperhatikan beberapa teks untuk menunjukkan bagaimana ketegangan tersebut muncul dalam Alkitab sendiri.

\section{YosUa ATAU HAKIM-HAKIM?}

Setelah disinggung berulang-ulang, sekarang kita akan menengok Kitab Yosua yang selalu dijadikan contoh kalau orang berbicara tentang tema kekerasan ini. Kekerasan ini dapat dilihat terutama dalam kisah perebutan Tanah Kanaan.

Dalam kisah penyerbuan masuk ke Tanah Terjanji seperti diceritakan dalam kitab Yosua, kita temukan teks-teks yang bernada haus darah seperti, "Mereka menumpas ( $\mathrm{hrm}$ ) dengan mata pedang segala sesuatu yang di dalam kota itu, baik laki-laki maupun perempuan, baik tua mau-pun muda, sampai kepada lembu, domba dan keledai" (Yos. 6,21; atau juga 8,22; 10,26.28.30.32, dsb.). Menariknya, tindakan

27 Kendati harus dikatakan juga bahwa dalam konteks liturgi Gereja Katolik, pilihan bacaan untuk Perayaan Ekaristi yang terdapat dalam Lectionarium yang menghilangkan teks-teks teror sebenarnya juga dapat dipandang sebagai sebuah textual cleansing sehingga Alkitab dapat tampil dengan lebih pantas. Bdk. Philip Jenkins, Laying Down the Sword, p. 16. 
seperti itu diklaim mendapatkan legitimasi religius sebagai perintah yang diberikan oleh YHWH sendiri. Misalnya,

Seperti yang diperintahkan TUHAN kepada Musa, hamba-Nya itu, demikianlah diperintahkan Musa kepada Yosua dan seperti itulah dilakukan Yosua: tidak ada sesuatu yang diabaikannya dari segala yang diperintahkan TUHAN kepada Musa. ... Karena TUHAN yang menye-babkan hati orang-orang itu menjadi keras, sehingga mereka berperang melawan orang Israel, supaya mereka ditumpas, dan jangan dikasihani, tetapi dipunahkan, seperti yang diperintahkan TUHAN kepada Musa (Yos. 11:15.20 bdk. Ul. 7:1-5).

Gambaran yang ditampilkan oleh kitab Yosua memang menyeramkan. Sekali lagi, kisah ini dapat menjadi batu sandungan kalau kita mau memikirkan gambaran Allah yang muncul dari teks seperti itu. Tetapi apakah ini satu-satunya kisah yang menceritakan masuknya bangsa Israel ke Tanah Terjanji?

Untunglah jawabannya: Tidak! Kita mempunyai gambaran lain tentang masuknya bangsa Israel ke Tanah Terjanji yang sama sekali berbeda dengan yang digambarkan oleh kitab Yosua. Versi itu terdapat dalam bagian awal kitab Hakim-hakim (Hak. 1). Bahwa kitab Hakimhakim 1 merupakan versi lain dari kisah perebutan Tanah Terjanji menjadi jelas bila kita membandingkan kitab Hakim-hakim 2:6-8 dengan kitab Yosua 24:28-30. Kedua teks itu menceritakan kematian Yosua yang terjadi setelah bangsa Israel masuk ke Tanah Terjanji dengan bahasa yang mirip. Dengan kata lain, kitab Yosua yang diakhiri dengan Yosua 24:28-30 menceritakan satu versi perebutan Tanah Terjanji. Sementara itu, kitab Hakim-hakim 1 yang diakhiri dengan keterangan mengenai kematian Yosua (Hak. 2:6-8) juga mengisahkan apa yang terjadi sebelum Yosua mati, yaitu perebutan Tanah Terjanji. Hanya saja versi Hak memang lebih singkat. Lalu apa yang kita temukan dalam kitab Hakim-hakim 1 ?

Yang jelas, tidak ada gambaran pembantaian bangsa-bangsa asing (yang tanahnya direbut oleh bangsa Israel), kecuali mungkin kisah tentang Adoni-Bezek yang dipotong ibu jari tangan dan kakinya (Hak. 1,6). 
Rumusan "Suku X (salah suku Israel) tidak menghalau penduduk Y atau $\mathrm{Z}$ (bangsa asing)" muncul secara konsisten dalam Hak 1. Rumusan "tidak menghalau" (lo horish: to expell, mengusir) muncul 8 kali dalam kitab Hakim-hakim 1,16-36 yang mengisahkan bagaimana Israel memasuki Kanaan. Penggunaan yang begitu sering itu seakan-akan mau memberikan tekanan kuat bahwa menurut Hak. 1 bangsa Israel memang tidak meng-halau mereka dari tempat mereka, apalagi membantai mereka. Dengan kata lain, mereka tetap dibiarkan hidup berdampingan dengan bangsa pilihan Tuhan.

Demikianlah, kita mempunyai dua kisah yang bertolak belakang walau yang dikisahkan sebenarnya hal yang sama. Baik kitab Hakimhakim 1 maupun kitab Yosua 1-12 sebenarnya mengisahkan hal yang sama tetapi dengan cara yang berbeda. ${ }^{28}$

Sekali lagi, ini menunjukkan bahwa tentang perang, Alkitab kanonik tidak hanya menyuarakan satu suara saja, tetapi menghadapkan Gereja dengan beberapa perspektif yang muncul dari konteks susastra dan konteks sejarah yang berbeda. ${ }^{29} \mathrm{Di}$ antara mereka, tidak ada satu versi yang lebih benar dari versi yang lain. Bahkan dibaca dari sudut lain, versi Kitab Hakim-hakim sebenarnya sebuah kritik tandingan atas gambaran versi Yosua yang terlalu vulgar seperti itu.

\section{Gaya Nuh atau Abraham? ${ }^{30}$}

Untuk contoh lain, kita dapat mulai dengan membuka bagian awal Alkitab. Kalau kita mengikuti narasi penciptaan, akan kelihatan bahwa sesudah Allah menciptakan alam semesta dengan segala isinya yang Ia nilai sebagai "baik adanya," mulailah kisah tentang perjalanan dosa

28 E. Theodor Mullen, "Judges 1:1-36: The Deuteronomistic Reintroduction of the Book of Judges," Harvard Theological Review 77 (1984): 34.

29 L. Daniel Hawk, "The God of the Conquest: The Theological Problem of the Book of Joshua," Bible Today 46 (2008): 144.

30 Inspirasi untuk bagian ini dan bagian berikutnya diambil dari John Dominic Crossan, God E Empire (New York: HarperCollins, 2007), pp. 62-65; 82-88 yang juga menggunakan teks tersebut tetapi dalam konteks yang berbeda. 
manusia. Dimulai dengan jatuhnya Adam dan Hawa (Kej. 3) yang segera disambung dengan homisidia pertama yang juga adalah fratrisidia saat Kain membunuh saudaranya Habel (Kej. 4). Situasi ini tampaknya berlanjut terus sampai pada titik tertentu di mana Allah menilai,

.... bahwa kejahatan manusia besar di bumi dan bahwa segala kecenderungan hatinya selalu membuahkan kejahatan semata-mata, maka menyesallah TUHAN, bahwa Ia telah menjadikan manusia di bumi, dan hal itu memilukan hati-Nya. Berfirmanlah TUHAN: “Aku akan menghapuskan manusia yang telah Kuciptakan itu dari muka bumi, baik manusia maupun hewan dan binatang-binatang melata dan burung-burung di udara, sebab Aku menyesal, bahwa Aku telah menjadikan mereka." Tetapi Nuh mendapat kasih karunia di mata TUHAN (Kej. 6:5-8).

Adapun bumi itu telah rusak di hadapan Allah dan penuh dengan kekerasan. Allah menilik bumi itu dan sungguhlah rusak benar, sebab semua manusia menjalankan hidup yang rusak di bumi. Berfirmanlah Allah kepada Nuh: "Aku telah memutuskan untuk mengakhiri hidup segala makhluk, sebab bumi telah penuh dengan kekerasan oleh mereka, jadi Aku akan memusnahkan mereka bersama-sama dengan bumi" (Kej. 6:11-13).

Masalahnya kiranya jelas. Allah melihat bahwa manusia yang diciptakan-Nya "sungguh amat baik" (bdk. Kej. 1,31) ternyata dalam perjalanan sejarah telah berubah menjadi sungguh amat buruk. Secara harafiah, dalam kitab Kejadian 6:5 dikatakan bahwa "kejahatan manusia besar di bumi" dan bahwa segala rencana/kecenderungan hatinya (mahsebot libbo) sepanjang hari (kol-hayyom) hanyalah kejahatan. Dalam kitab Kejadian 6:11 dikatakan bahwa dunia ini penuh dengan kekerasan (hamas). Perhatikan bahwa situasi ini dilukiskan dua kali dengan menghamburkan kata-kata yang mirip (perhatikan kata: kejahatan, menyesal, kekerasan, rusak). Gambaran ini hanya mau menunjukkan sebuah situasi manusia yang tak tertolong lagi. Hopeless!

Melihat situasi itu, dikatakan bahwa TUHAN menyesal karena telah menjadikan manusia (diulang dua kali dalam ayat 6 dan 7) dan hal ini memilukan hati-Nya. Lalu TUHAN mengambil keputusan untuk meng- 
hapuskan manusia dari muka bumi. Dan apa yang kemudian terjadi? Kita semua tahu bahwa kitab Kejadian 7-9 menceritakan kisah air bah yang menghancurkan segala-galanya, kecuali satu keluarga, yaitu keluarga Nuh! “Demikianlah dihapuskan Allah segala yang ada, segala yang di muka bumi, baik manusia maupun hewan dan binatang melata dan burung-burung di udara, sehingga semuanya itu dihapuskan dari atas bumi;" hanya Nuh yang tinggal hidup dan semua yang bersamasama dengan dia dalam bahtera itu" (Kej. 7:23).

Ada kejahatan di bumi ini dan jalan keluar yang dipilih Allah untuk menyelesaikan soal ini adalah membinasakan semua makhluk hidup; tidak hanya manusia tetapi juga hewan dan binatang melata bahkan burungburung di udara (tidak tahu bagaimana halnya dengan ikan yang hidup di air). Kendati kekerasan (Allah) diletakkan dalam konteks menyelesaikan problem kejahatan atau untuk melindungi ciptaan lain, ${ }^{31}$ substansinya tetap sama: kekerasan tetap adalah kekerasan. Apalagi kalau kita membayangkan pertanyaan-pertanyaan berikut secara simplistis: apakah memang benar bahwa semua yang menjadi korban air bah adalah mereka yang memang pantas menerima hukuman itu? Apakah memang hanya Nuh seorang yang benar di hadapan Allah? Apakah air bah dapat "membedakan" orang benar dan orang jahat? Kalau kita membaca kitab Yunus, jelas bahwa angin ribut dan badai besar menghantam kapal yang ditumpangi Yunus yang melarikan diri dari Tuhan dan membuat semua awak kapal — tanpa pilih-pilih—menjadi ketakutan, sementara Yunus malahan justru tidur nyenyak (Yun. 1:4-6).

Apakah air bah merupakan sarana yang efektif untuk membasmi kejahatan? Sulit untuk menjawab, tetapi rasa-rasanya tidak. Setidaktidaknya, secara tradisional kisah menara Babel yang terdapat dalam kitab Kejadian 11:1-9 dianggap sebagai dosa keangkuhan manusia untuk menentang Allah. Dosa rupanya tetap berlangsung di antara umat manusia. Lalu bagaimana pemecahan yang diambil oleh Allah? Kalau kita memperhatikan kisah berikutnya, rasanya kita menemukan cara lain untuk meng-

31 Jerome F.D. Creach, Violence in Scripture, p. 11. 
hadapi problem kejahatan, sebuah cara yang sama sekali berbeda dengan yang pernah diambil sebelumnya.

Dalam kitab Kejadian 12:1-3 kita menemukan teks berikut:

Berfirmanlah TUHAN kepada Abram, "Pergilah dari negeri ini dan dari sanak saudaramu dan dari rumah bapamu ini ke negeri yang akan Kutunjukkan kepadamu. Aku akan membuat engkau menjadi bangsa yang besar, dan memberkati engkau serta membuat namamu masyhur; dan engkau akan menjadi berkat. Aku akan memberkati orang-orang yang memberkati engkau, dan mengutuk orang-orang yang mengutuk engkau, dan olehmu semua kaum di muka bumi akan mendapat berkat.

Apa arti teks ini? Kita dapat mengartikan teks ini sebagai pemecahan lain sebagai alternatif solusi penuh kekerasan yang ditawarkan kisah Nuh. Dalam kisah Nuh, satu orang benar dipilih untuk diselamatkan sementara semua yang lain dibasmi, dimusnakan tanpa ampun; dalam kisah Abraham, satu orang benar dipilih membawa berkat bagi "semua kaum di muka bumi."

Dengan demikian, di sini kita berhadapan dengan dua model pemecahan yang dipilih Allah untuk menghadapi problem kejahatan: gaya Nuh dan gaya Abraham. Solusi gaya Nuh berarti membasmi banyak orang (yang dianggap jahat) demi yang sedikit (Nuh yang dianggap benar); sementara solusi gaya Abraham berusaha merangkul yang banyak oleh yang sedikit. Dengan demikian menjadi jelas bahwa Allah (atau Alkitab) tidak hanya mempunyai satu pemecahan terhadap suatu problem tertentu, dalam hal ini problem kejahatan, tetapi dua pemecahan yang bahkan saling bertolak belakang! Menarik memperhatikan bahwa ketika Allah mau menunggangbalikan Sodom dan Gomora, Abraham memberi-kan komentar yang rasanya mau menyindir Allah, "Jauhlah kiranya dari pada-Mu untuk berbuat demikian, membunuh orang benar bersama-sama dengan orang fasik, sehingga orang benar itu seolah-olah sama dengan orang fasik! Jauhlah kiranya yang demikian dari pada-Mu! Masakan Hakim segenap bumi tidak menghukum dengan adil?" (Kej. 18:25). Allah seperti digambarkan dalam Alkitab sebenarnya menampilkan sikap yang mendua. 


\section{HARMAgedon ATAU Sion?}

Sikap mendua dari Alkitab tercermin juga dalam kontras berikut. Sekali lagi, bagian ini berhadapan dengan problem kejahatan. Seperti kita sadari, problem kejahatan adalah ancaman bagi teisme. Fakta adanya kejahatan merupakan senjata ampuh yang paling sering dikutip untuk membuktikan bahwa Allah itu tidak ada. Lalu kita dapat bertanya, bagaimana Alkitab memberikan jawaban terhadap problem kejahatan ini?

Secara tradisional, ada keyakinan bahwa pada suatu saat kelak di masa depan Allah akan menghancurkan para penguasa yang memerintah Israel dan dunia secara tidak adil. Pertarungan terakhir ini diyakini akan terjadi di suatu tempat simbolik yang disebut Harmagedon di mana kebaikan akan menghancurkan kejahatan untuk selama-lamanya. Kemenangan ini dicapai melalui tindak kekerasan yang dijalankan oleh yang ilahi. Harmagedon: di dalam Alkitab hanya muncul sekali di dalam kitab Wahyu 16:16. Secara etimologis, kata ini dianggap berasal dari kata har (gunung) dan Megiddo (nama kota). Akan tetapi, sulit untuk menentukan secara geografis karena di sekitar Megiddo, tidak ada gunung yang dapat diidentifikasi sebagai Gunung Megiddo. Kota Megiddo terletak di lembah Yizreel, dan bukan pada sebuah gunung. ${ }^{32}$

Dari perspektif alkitabiah, beberapa teks dengan jelas menunjukkan arah ini:

Aku akan membalas dendam dengan murka dan kehangatan amarah, kepada bangsa-bangsa yang tidak mau mendengarkan (Mi. 5:14).

Musuhku akan melihatnya dan dengan malu ia akan menutupi mukanya, dia yang berkata kepadaku: “Di mana TUHAN, Allahmu?" Mataku akan memandangi dia; sekarang ia diinjak-injak seperti lumpur di jalan. Biarlah bangsa-bangsa melihatnya dan merasa malu atas segala keperkasaan mereka; biarlah mereka menutup mulutnya dengan tangan, dan telinganya menjadi tuli. Biarlah mereka menjilat debu seperti ular, seperti binatang menjalar di bumi; biarlah mereka keluar

32 Mitchell G. Reddish, Revelation (Macon: Smyth \& Helwys, 2001), pp. 312-313. 
dengan gemetar dari kubunya, dan datang kepada TUHAN, Allah kami, dengan gentar, dengan takut kepada-Mu! (Mi. 7:10;16-17).

"Siapa dia yang datang dari Edom, yang datang dari Bozra dengan baju yang merah, dia yang bersemarak dengan pakaiannya, yang melangkah dengan kekuatannya yang besar?" "Akulah yang menjanjikan keadilan dan yang berkuasa untuk menyelamatkan!" "Mengapakah pakaian-Mu semerah itu, dan baju-Mu seperti baju pengirik buah anggur?" "Aku seorang dirilah yang melakukan pengirikan, dan dari antara umat-Ku tidak ada yang menemani Aku! Aku telah mengirik bangsa-bangsa dalam murka-Ku, dan Aku telah menginjak-injak mereka dalam kehangatan amarah-Ku; semburan darah mereka memercik kepada baju-Ku, dan seluruh pakaian-Ku telah cemar. Sebab hari pembalasan telah Kurencanakan dan tahun penuntutan bela telah datang. Aku melayangkan pandangan-Ku: tidak ada yang menolong; Aku tertegun: tidak ada yang membantu. Lalu tangan-Ku memberi Aku pertolongan, dan kehangatan amarah-Ku, itulah yang membantu Aku. Aku memijak-mijak bangsa-bangsa dalam murka-Ku, menghancurkan mereka dalam kehangatan amarah-Ku dan membuat semburan darah mereka mengalir ke tanah" (Yes. 63:1-6).

Lalu malaikat itu mengayunkan sabitnya ke atas bumi, dan memotong buah pohon anggur di bumi dan melemparkannya ke dalam kilangan besar, yaitu murka Allah. Dan buah-buah anggur itu dikilang di luar kota dan dari kilangan itu mengalir darah, tingginya sampai ke kekang kuda dan jauhnya dua ratus mil. (Why. 14:19-20).

Menyimak gambaran yang ditampilkan teks-teks eksemplaris di atas, kita dapat merasakan betapa nuansa kekerasan muncul dengan amat kuat. Dan sekali lagi, sang pelaku kekerasan adalah Allah sendiri. Ini adalah cara yang dipilih Allah untuk menghadapi problem kejahatan. Tetapi apakah ini satu-satunya jalan?

Mengingat uraian di atas tentang gaya Nuh dan Abraham, kita tahu bahwa jawab atas pertanyaan itu adalah: Tidak! Di dalam Alkitab masih ada skenario lain untuk penyelesaian problem kejahatan. Skenario ini tidak lagi melibatkan sebuah Pertempuran Terakhir, tetapi lebih merupakan suatu Perjamuan Terakhir; bukan Last Battle tetapi Last Supper. 
Tempatnya bukan lagi Gunung Megiddo sebagai medan pertempuran terakhir, tetapi Gunung Zion sebagai tempat perjamuan. ${ }^{33}$

Beberapa teks dapat kita tampilkan. Teks pertama adalah teks yang hampir selalu menjadi bahan pembicaraan para ahli karena hampir verbatim terdapat dalam dua tradisi kenabian yang berbeda walaupun mereka berasal dari periode yang kurang lebih sama. Kita lihat kitab nabi Yesaya 2:2-4 dan kitab nabi Mikha 4:1-3:

Akan terjadi pada hari-hari yang terakhir: gunung rumah TUHAN akan berdiri tegak mengatasi gunung-gunung dan menjulang tinggi di atas bukit-bukit; bangsa-bangsa akan berduyun-duyun ke sana, dan banyak suku bangsa akan pergi serta berkata: "Mari, kita naik ke gunung TUHAN, ke rumah Allah Yakub, supaya Ia mengajar kita tentang jalanjalan-Nya dan supaya kita berjalan menempuhnya; sebab dari Sion akan keluar pengajaran, dan firman TUHAN dari Yerusalem." Ia akan menjadi hakim antara banyak bangsa, dan akan menjadi wasit bagi suku-suku bangsa yang besar sampai ke tempat yang jauh; mereka akan menempa pedang-pedangnya menjadi mata bajak, dan tombaktombaknya menjadi pisau pemangkas; bangsa tidak akan lagi mengangkat pedang terhadap bangsa, dan mereka tidak akan lagi belajar perang. Tetapi mereka masing-masing akan duduk di bawah pohon anggurnya dan di bawah pohon aranya dengan tidak ada yang mengejutkan, sebab mulut TUHAN semesta alam yang mengatakannya (Mi. 4:1-4 bdk. Yes. 2:2-4).

TUHAN semesta alam akan menyediakan di gunung Sion ini bagi segala bangsa-bangsa suatu perjamuan dengan masakan yang bergemuk, suatu perjamuan dengan anggur yang tua benar, masakan yang bergemuk dan bersumsum, anggur yang tua yang disaring endapannya. Dan di atas gunung ini TUHAN akan mengoyakkan kain perkabungan yang diselubungkan kepada segala suku bangsa dan tudung yang ditudungkan kepada segala bangsa-bangsa. Ia akan meniadakan maut untuk seterusnya; dan Tuhan ALLAH akan menghapuskan air mata dari pada segala muka; dan aib umat-Nya akan dijauhkan-Nya dari seluruh bumi, sebab TUHAN telah mengatakannya (Yes. 25:6-8).

33 John Dominic Crossan, God \& Empire, p. 85. 
Silakan menyimak beberapa gagasan indah yang muncul dalam teks di atas. Rumusan "pada hari-hari yang terakhir" menunjuk pada suatu saat eskatologis tertentu di masa depan, ketika relasi baru antara Allah dan manusia, Israel dan bangsa-bangsa terbentuk. ${ }^{34}$ Dan masa itu, bangsa-bangsa (goyim rabim) berbondong-bondong datang ke gunung rumah TUHAN, menghadap Allah di dunia tanpa kekerasan dan perang untuk belajar Hukum-hukum Tuhan. Dengan amat jelas dikatakan bahwa senjata-senjata diubah menjadi alat-alat pertanian. Sarana untuk mem-bunuh diubah menjadi sarana yang akan memberi kehidupan. Jika gambaran ini dilengkapi dengan teks kedua, kitab nabi Yesaya 25:6-8 kelihatan bahwa Sion menjadi tempat perjamuan yang benar-benar mewah. Allah adalah Panitia penyelenggara pesta perjamuan itu. Dengan demikian menjadi jelas bahwa menurut teks di atas, kesimpulan terakhir dari perang melawan kejahatan bukanlah kekerasan yang membinasakan, tetapi perjamuan mewah yang merangkul semua.

Mencermati dua arus ini, sekali lagi menjadi jelas bahwa di hadapan problem kejahatan, Alkitab tidak memberikan satu jawaban tunggal yang begitu pasti, tetapi menawarkan dua kemungkinan yang tentu saja selalu dapat dipilih. Pembasmian dengan kekerasan bukanlah satu-satunya penyelesaian; masih ada kemungkinan lain, yaitu penyelesaian tanpa kekerasan.

\section{HIDUP DALAM KETEGANGAN}

Dari paparan di atas, tampak bahwa kekerasan dan kegarangan bukanlah satu-satunya suara yang diwartakan oleh Alkitab. Masih ada suara lain yang lebih bersifat non-kekerasan, yang lembut dan menyejukkan. Bahkan di tengah satu tradisi alkitabiah tertentu, dapat kita temukan juga gagasan yang berbeda. Sebagai contoh dapat dilihat bahwa di tengah gemuruh pemusnahan penduduk negeri dalam Kitab Yosua, kita menemukan juga kisah tentang Rahab yang diselamatkan. ${ }^{35}$

34 Gary V. Smith, The NIV Application Commentary: Hosea/Amos/Micah (Grand Rapids: Zondervan, 2001), p. 509.

35 Bdk. Jerome F.D. Creach, Violence in Scripture, p. 6. 
Menurut catatan yang diberikan oleh Dei Verbum di atas, dalam menafsirkan Alkitab orang tetap mesti memperhitungkan isi dan kesatuan seluruh Alkitab. Kalau begitu, pertanyaan sehubungan dengan kekerasan (Allah) di dalam Alkitab seharusnya tidak boleh ditonjolkan terlalu berlebihlebihan sehingga menenggelamkan suara lain yang menyejukkan. Dengan kata lain, mempersoalkan kekerasan (Allah) dalam Alkitab tanpa memberi tempat pada suara lain yang berbeda sebenarnya kurang fair.

Gereja tidak hanya menerima (bagian) Alkitab yang menyerukan genderang kegarangan perang dengan pedang dan api; tetapi Gereja juga merengkuh (bagian) Alkitab yang menyenandungkan kedamaian yang menyejukkan yang diwarnai dengan kasih dan kelembutan. Kita mempunyai lagu "Onward Christian Soldiers" tetapi juga "Tuhan adalah Gembalaku." Kita tidak dapat menomorsatukan yang satu dan menutup mata bagi yang lain walau itu berarti bahwa kita mesti hidup dalam ketegangan.

Penulis menyadari bahwa menunjukkan adanya ambiguitas sikap dalam menghadapi kekerasan hanya merupakan langkah awal untuk memahami topik "kekerasan dalam Alkitab." Masih ada banyak pertanyaan yang harus diperhatikan. Kita masih dapat berkomentar: "Ya, kita tahu bahwa Alkitab membawa kita kepada ketegangan. Tetapi bagaimana kita memahami teks-teks yang bernuansa kekerasan?" Atau, sebagai orang Kristen, kita juga dapat bertanya: "Bagaimana peranan Yesus Kristus dalam hal ini?" Perwahyuan Allah yang terjadi secara bertahap itu akhirnya memuncak dan mencapai kepenuhannya dalam diri Yesus Kristus, "Firman yang telah menjadi manusia” (Yoh. 1:14; bdk. DV, 4). Kalau demikian, maka gambaran Allah sebagaimana muncul dalam tulisan-tulisan Perjanjian Lama, sebenarnya perlu disempurnakan oleh gambaran Allah yang dihadirkan oleh Yesus Kristus. Oleh karena itu, penafsiran Alkitab mestinya juga memperhitungkan " a Christocentric hermeneutic - or Christ-centered method of interpretation." ${ }^{36}$

36 Eric A. Seibert, Disturbing Divine Behavior, p. 185. 
Tentu saja masih banyak pertanyaan yang membutuhkan kesempatan lain untuk menanggapinya. Tetapi paling tidak, kita perlu menyadari ter-lebih dahulu bahwa nuansa kekerasan bukanlah satu-satunya topik dalam Alkitab yang patut mendapat perhatian.

\section{PENUTUP}

Demikianlah, menimbang ulang teks-teks kekerasan dalam Alkitab dalam perspektif ajaran Gereja Katolik ternyata memberikan tawaran rambu-rambu yang semestinya diperhatikan khususnya oleh orang Katolik. Seandainya rambu-rambu itu sungguh diperhitungkan oleh orang Katolik dalam membaca Alkitab, teks-teks alkitabiah yang selama ini dianggap menebarkan terror dan kekerasan mestinya tidak perlu lagi menjadi sandungan. Teks alkitabiah tetap tidak berubah, tetapi cara membaca teks itu yang berubah.

Dalam sejarah pergulatan manusia untuk memahami masalah kekerasan yang tercantum dalam Alkitab, tulisan ini berharap dapat menjadi masukan untuk menambah bahan pada bola salju raksasa yang sedang menggulir. Bola salju masih berada di tengah jalan. Harus diakui bahwa titik awalnya memang sebuah pandangan dogmatis dari suatu perspektif tertentu, yaitu perspektif ajaran tradisi Katolik. Meskipun demikian, pandangan tersebut rasanya tetap dapat juga ditawarkan kepada dunia lebih luas. Oleh karena itu, masukan lanjutan yang lebih tajam dan bernuansa dapat dinantikan untuk mencerahkan dan memperkaya kita semua dalam memahami kekerasan dalam Alkitab.

\section{DAFTAR RUJUKAN}

Barton, John. Reading the Old Testament. London: Darton, Longman, and Todd, 1984.

Béchard, Dean P. The Scripture Documents. Collegeville: The Liturgical Press, 2002.

Benediktus XVI. Anjuran Apostolik Verbum Domini, 30 September 2010.

Copan, Paul. Is God a Moral Monster? Grand Rapids: BakerBooks, 2011. 
Creach, Jerome F.D. Violence in Scripture. Louisville: Westminster John Knox, 2013.

Crossan, John Dominic. God E Empire. New York: HarperCollins, 2007.

Daniel Hawk, L. "The God of the Conquest: The Theological Problem of the Book of Joshua." Bible Today 46 (2008): 141-147.

Davies, Eryl W. The Immoral Bible: Approaches to Old Testament Ethics. London - New York: T\&T Clark, 2010.

Dawkins, Richard. The God Delusion. London: Bantam Press, 2006.

Dean P. Béchard. The Scripture Documents. Collegeville: The Liturgical Press, 2002.

Ehrman, Bart D. Lost Christianities. New York: Oxford University Press, 2003.

Filipi, Alfio e Erminio Lora. Enchiridion Biblicum: Documenti della chiesa sulla sacra scrittura. Bologna: EDB, 1993.

Holmes, Peter (Trans.). The Five Books of Quintus Sept. Flor: Tertullianus against Marcion. Edinburgh: T\&T Clark, 1868.

Jacobs, Tom. Konstitusi Dogmatis "Dei Verbum" tentang Wahju Ilahi. Jogjakarta: Kanisius, 1969.

Jenkins, Philip. “Dark Passages" in Boston Globe edisi 8 Maret 2009. http:/ /www.boston.com/bostonglobe/ideas/articles/2009/03/08/ dark_passages/?page=full. Diakses pada 18 Juni 2014.

. Laying Down the Sword: Why We Can't Ignore the Bible's Violent Verses. New York: HarperOne, 2011.

Lowrett, Lori L. Joshua and the Rhetoric of Violence. Sheffield: Sheffield Academic Press, 1996.

McDonald, Patricia M. God E Violence. Scotdalle: Herald Press, 2004.

Räisänen, Heikki, "Marcion." In A Companion to Second-Century Christian 'Heretic,' eds. Antti Marjanen \& Petri Luomanen. Leiden: Brill, 2005, pp. 100-124.

Reddish, Mitchell G. Revelation. Macon: Smyth \& Helwys, 2001. 
Seibert, Eric A. Disturbing Divine Behavior. Minneapolis: Fortress Press, 2009.

Smith, Gary V. The NIV Application Commentary: Hosea/Amos/Micah. Grand Rapids: Zondervan, 2001.

Theodor Mullen, E. “Judges 1:1-36: The Deuteronomistic Reintroduction of the Book of Judges." Harvard Theological Review 77 (1984): 34-54.

Wolterstorf, Nicholas. "Reading Joshua." In Divine Evil?: The Moral Character of the God of Abraham, ed. Michael Bergmann. New York: Oxford University, 2011.

Zvi Bettler, Marc, Peter Enns, and Daniel Harrington. The Bible and the Believers. New York: Oxford University, 2011. 